\title{
ADOLESCENT MORAL DEVELOPMENT IN FAMILIES
}

\author{
Ujang Dedih \\ Universitas Islam Negeri (UIN) Sunan Gunung Djati Bandung \\ Jl. A. H. Nasution No. 105 Cibiru, Bandung, Jawa Barat, Indonesia, 40614 \\ Email: dedihujang745@gmail.com
}

Received: 04, 2018. Accepted: 01, 2019. Published: 01, 2019.

\begin{abstract}
This study aimed to investigate parents' goals and objectives in fostering the moral values to their adolescents, parents' moral values instilled toward their teenagers, parents' approach and methods in instilling moral values, and parents' guidance development in nurturing moral values toward adolescent. This research used descriptive-analytic method, and qualitative-naturalistic approach. It applied observation, interview and documentation. It investigated three families with a different education background. Findings show that family with undergraduate education background is relatively very good in fostering the values of Akhlak Karimah to their teenagers. Their success was supported by clear goals and objectives, consistent and continuous delivery of materials, the use of appropriate approaches and methods, and good and harmonious family. These factors contributed to excellent moral education for their teenager. Family with a high school education background applied moral education using the formulation of objectives, materials, and the arrangement of a family atmosphere but the result was less optimal because they used less precise methods and approaches. Family with a junior high school education background had not achieved a satisfactory result in moral education for their teenagers because they did not formulate well objectives, materials, methods, approaches and the arrangement of a family atmosphere
\end{abstract}

Keywords: Character, Children, Education, Islamic Perspective

\begin{abstract}
ABSTRAK
Tujuan dari penelitian ini adalab untuk menyelidiki tujuan dan sasaran orang tua dalam menumbubkan nilai-nilai moral bagi remaja mereka, nilai-nilai moral orang tua ditanamkan kepada remaja mereka, pendekatan orang tua dan metode dalam menanamkan nilai-nilai moral, pengembangan bimbingan orang tua dalam memelihara nilai-nilai moral terhadap remaja. Penelitian ini menggunakan metode deskriptif-analitik, dan pendekatan kualitatif-naturalistik. Penelitian ini menerapkan observasi, wawancara dan dokumentasi. Penelitian ini menyelidiki tiga keluarga dengan latar belakang pendidikan yang berbeda. Hasil penelitian menunjukkan bahwa keluarga dengan latar belakang pendidikan sarjana relatif sangat baik dalam menumbubkan nilai-nilai Akhlak Karimah kepada anak remaja mereka. Keberhasilan mereka didukung oleh tujuan dan sasaran yang jelas, pengiriman materi yang konsisten dan berkelanjutan, penggunaan pendekatan dan metode yang tepat, dan keluarga yang baik dan harmonis. Faktor-faktor ini berkontribusi pada pendidikan moral yang sangat baik untuk anak remaja mereka. Keluarga dengan latar belakang pendidikan sekolah menengah, menerapkan pendidikan moral menggunakan perumusan tujuan, bahan, dan pengaturan suasana keluarga tetapi hasilnya kurang optimal karena mereka menggunakan metode dan pendekatan yang kurang tepat. Sementara keluarga dengan latar belakang pendidikan sekolah menengah pertama, belum mencapai hasil yang memuaskan dalam pendidikan moral untuk remaja mereka karena mereka tidak merumuskan dengan baik tujuan, bahan, metode, pendekatan dan pengaturan suasana keluarga.
\end{abstract}

Kata Kunci: Karakter, Remaja, Pendidikan, Perspektif Islam 


\section{INTRODUCTION}

In cultural perspective, Education can be defined as an effort to cultivate people through the process of fostering values existed in society (Ramayulis, 1996; Syam, 1988). It tries to instill the values that develop in society including religious, ethical, moral, intellectual, artistic, political, economic, social, cultural and so on. It serves as the instrument for the government to build their next generation in terms of their character and another aspect to be a good citizen (Nadhif, 2016). It is very crucial to develop the next generation to ensure the national survival.

Education, as defined by Tafsir (1992), entails personal development in all aspects; body, mind, and heart. This view is in line with John Dewey quoted by Tafsir (1992), education "... the process of forming fundamental dispositions, intellectual and emotional, towards nature and fellow men". Functionally speaking, education can be classified as education for yourself, others (school), community and family. Its process in these institutions involves various parties who are responsible for the realization of faithful and devoted human beings and good behavior. These institutions involve the government in Islamic madrasa (Abu et al., 2015); and family institution (Bawazir et al., 2009).

Every nation has an educational purpose in accordance with its philosophy and values that its people uphold. The purpose of education is like "clothes" that need to be measured and sewn according to the shape and size of the users, their identity, and their view of life in the society of a country (Shihab, 1992). In Indonesia, the purpose of education is stated in Law No. 02 of 1989, Chapter II Article 4. Its purpose is to generate good Indonesian citizen. In addition, they have characters as someone who believes and fear God and possess "noble character". In Idealistic-religious education goals, noble character is also called as akblak karimah. To achieve this character, the government needs to support the acquisition of physical and spiritual aspects, reflected in the intact and solid personality.

In Indonesia, the educational goal is aimed at achieving noble character. The goal should be applied to all educational institutions at every level. Furthermore, all educational activities in Indonesia are required to implement the formulation of educational objectives. One of its objectives is to build morale and character. In the context of pesantren, character education has been implemented usually in the figure exemplary of kyai (Hidayat, 2016). Kyai figure is influential especially for santri who live and interact with kyai for their daily life in pesantren. It goes without saying that kyai will set a good example for santri.

In addition to pesantren, Indonesia has another institution to instill moral and character education that is a family institution. Families play an important role in moral education. This has been considered by the government through UUSPN No. 02 of 1989, article 10 paragraph (5): "The family plays important role in education. The government recognizes the independence of the family to carry out educational efforts in its own environment". This recognition indicates that family institution has to be taken into account when aiming at preparing the next generation to possess noble character.

Family raises children who grow to be adolescent in their life stage. Adolescent need moral knowledge and development in their family. They should have the process of moral coaching in their family. Their developmental period may experience behavioral shock and they may experience personal and behavioral difficulties. Therefore their crucial development requires special understanding from their parents and educators (Bawazir et al., 2009). They could not be separated from their parent's influence and relationship to proceed their life in their growth and development as an adolescent.

Parents play an important role as the main educator in the family. They should provide solutions to the difficulties that adolescent faced through harmonious communication (dialogue) between family members (Rifai, 1984). Muntaha \& Wekke (2017) show that 
education in the family for adolescents include their intellectuals and manners. According to Juli Ariani's (2016), families play an important role in moral adjustment for their adolescent. Those researchers paid special attention toward the parent's role for adolescent moral development especially in terms of their intellectual and behavior.

Studies on adolescent in relation to moral or character education have been conducted by researchers. The topics include curriculum development, guidance and moral education for adolescent (Mosher \& Sullivan, 1976); Islamic perspective on moral developmental problem for adolescent (Hidajah, 2012); the development of adolescent moral and character education in madrasa (Abu et al., 2015); moral development for adolescent in pesantren (Hidayat, 2016); adolescent moral problem because of internet exposure (Ardi, Viola, \& Sukmawati, 2018). These research topics clearly show that adolescent moral development has attracted the researcher to investigate this issue.

Other topics for adolescent moral development include school institution in nurturing adolescent moral (Kanzal, 2016); family role in developing adolescent moral education (Bawazir et al., 2009); the role of the parent in a family to teach and nurture moral education for adolescent (Niwaz, Ishfaq, \& Attaulah, 2018).

However, the study investigated moral education for the adolescent in a family with different educational background. Education background has own characteristics and has different challenging circumstance to deal with adolescent moral development. The aim of this study was to investigate parents' goals in fostering the moral values to their adolescents, parents' moral values instilled toward their teenagers, parents' approach and methods in instilling moral values, and parents' guidance development in nurturing moral values toward adolescent.

\section{METHOD}

To reveal and explore the coaching process, a qualitative-naturalistic approach and descriptive methods were used. The data sources of this study included primary and secondary data sources. The primary data refers to three families. They were coded by HD (the first family), DM (the second family), and SP (the third family). They gave the main data source. They are biological father or mother for their adolescent. While adolescents referred to children who have reached the adolescence age (12-21 years old) who live with their parents at the time of this study. Secondary data sources in this study included the environment \& peers.

The data were collected by using three techniques namely: observation, interview, and documentation. Data were collected using direct observation of the interactions between parents and their adolescents in a natural situation, as it is. This is a feature of qualitativenaturalistic research.

Data were analyzed in several stages. The first step is an examination of all available data from various sources. The second stage is data reduction. It was an attempt to make a summary of the data. The third phase is to conduct units arrangement and categorization. The fourth step is the validity examination and last stage data interpretation.

\section{RESULTS AND DISCUSSION}

\section{Family Education Concept to Adolescents}

To foster moral development in adolescents in the family, this study refers to the principles of education that Lukman applied to his sons (Tafsir, 1992). He teaches his children the principle of Islamic education including the principles of monotheism, principles of worship obedience, moral principles, and amar ma 'ruf nabyi munkar.

The principle of monotheism is the essence and the ultimate spiritual experience that is one's taubid. Adolescent coaching in the family should be directed towards achieving the 
highest level of tauhid. They must believe in Allah SWT. To nurture this taubid, adolescents must be kept away from shirk, namely associating Allah with something else. They should be taught: the nature of the God with all its characteristics, the pillars of Faith toward God, angels, holy book, apostles, the end of day and faith in qadla and qadhar.

Principles of worship obedience are very important for an adolescent. They need to give understanding and practice about the principles of worship. They should be competent to carry out full compliance, khusü', sincerity worthy of a servant to the God almighty. The purpose of human creation is sole to worship him. Therefore, parents at home can educate prayer for children, especially for teenagers. Regular prayer practice is expected to make their faith and their mental stronger. Their moral and spiritual life will always be preserved from all immorality.

A prayer is a form of worship that is very fundamental for every Muslim. It can serve as an indicator for a Muslim. If one's prayer is good, then the rest of deeds are good. Conversely, if one's prayer is bad then the rest of deed are also bad. In addition, prayer is the pillar of one's Islam. If Muslim performs prayer means he has established a religion, whereas if he misses the prayer means he is considered to have undermined religion. a child in the family should be taught the prayer. Besides parents at home need to educate another type of worship such as zakat, fasting, and pilgrimage. These worship performances are expected to secure teenagers and maintain them from all negative things.

Achieving good morals and noble character are the goals of education. Educational practitioners need to understand that morals are very important to be taught to students. It can be done in several ways. Morals need to be instilled, accustomed and exemplified to adolescents in everyday life. These efforts can build adolescent good character or moral individually and socially in the community.

Principles of amar ma'ruf nahyi munkar mean that adolescent need to be educated to be capable of being constructive in improving people's lives. Adolescent need to be taught truth values by School, family, and society. They should be able to distinguish between good and bad, right and wrong both in the family and in society. Those values can be instilled in the family and it takes the role of parent to achieve this and implement in their family.

The principle shabr must be taught to adolescent. Adolescent need to learn to be patient individuals. They should be able to address their life's challenges since life is always not easy. Reaching their ideas and wishes in life is not always easy and sometimes often complicated. Given this challenge, a resilient and patient adolescent can overcome their life challenge. The above research paradigm can be drawn in Figure 1.

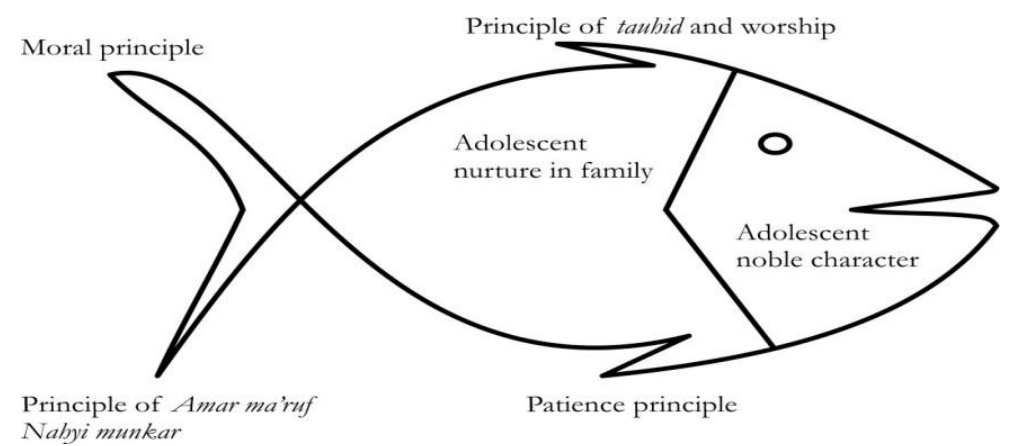

Figure I. Fish Bone Diagram for Research

\section{Parents' Objectives and Goal in Developing Adolescent Moral Values}

To investigate this research question, the interview was conducted to all families in this study. Based on the results of interviews with HD family, the father stated that the goals and 
objectives to be achieved in raising adolescents were to have pious children. They should be obedient to Allah and kind towards parents and behaves well with others. The expected moral character is reflected in adolescent daily life both in the home and in the community.

To achieve the goal of building this moral character, the HD family started its development since the age of the toddler, childhood, the process of entering adolescence and adulthood. Attempting to achieve the above goals, the HD family developed the tradition of reciting, learning discipline, examples of examples from father and mother including sending their children to Islamic Boarding Schools in order to gain religious knowledge. This is done when the children are off school or in their holiday. Those efforts were positive and supporting aspect to develop adolescent moral development.

In fostering obedience to Allah, HD families apply habituation and discipline in performing five daily prayers. This is done first of all to the older child in the hope that he can pass on the obedience habit of worship to his younger siblings. Also implanted in the HD family remind each other and advise in terms of carrying out the five daily prayers. In carrying out morning prayer HD always gives advice and develops criticism among his children. For example, in carrying out the dawn prayer the HD family instills habits, where children who get up firstly, they wake up their siblings. If there is a late sibling, other children developed constructive criticism that is criticism using satirical language. Being addressed satirically, late children feel embarrassed and in the following day, he can fix it.

The criticisms and advice in this family were developed not through the orders of their parents, but they were familiarized through constructive criticism by parents and children. In other words, there is an atmosphere of democracy in the family to educate this issue. In the context of establishing a moral character for their children, HD's parents encouraged their children to actively participate in religious activities. From this event, they could learn and gain moral lesson for their moral formation.

In fostering obedience to parents, HD family used several methods namely advice, commands and examples. Based on observation, HD family children were very respectful and obedient to everything that their parents ordered. HD family develop this obedience guidance in an atmosphere of harmonious interaction and communication. Based on observation, their adolescent never opposed or yelled at their parents. This adolescent behavior to their parents in the atmosphere and expression displayed respectful and obedient behavior to their parents.

Based on the interview result with DM family, the father expressed the goals to be achieved in fostering his children namely expecting a righteous child. The righteous children they expect was children who devoted to God and respectful to their parents. This expectation meets the religious teaching requirement. It encourages the parent to educate their children to be pious children.

Efforts to achieve the above goals, the DM family developed the tradition of reciting, learning discipline, examples from father and mother to include their children in the short religious course at Islamic Boarding School held by the nearest mosque in order to deepen their religious knowledge. This is done when the children are off school. Including in order to equip and instill in their children especially in terms of so that their children are able to read the Qur'an. DM's parents brought the Koran teacher to his home to deliver teaching Qur'an for their adolescent.

In fostering obedience to Allah, DM family implemented habituation and discipline in performing five daily prayers. This is done first of all for the oldest child in the hope that he could pass on the obedience habit of worship to his younger brother. In fostering obedience developed in the DM family, advice and habituation by parents in terms of performing five daily prayers. If the child is negligent in carrying out the five prayers when he does not hesitate to his parents, especially in this case, the mother snaps to perform prayer. It seemed that the 
mother had to conduct an authoritarian approach to ask her children to perform prayer when they showed their laziness to perform it.

SP family had goals and objectives to raise children namely the creation of good children. In the process, SP did not conduct daily coaching in order to achieve the above goals. It seems that it was not possible for parents in SP family to give examples, especially in terms of fostering obedience to Allah. Based on the observation, in daily life, the parents and their six children rarely carried out five daily prayers. In terms of fostering adherence to their parents in SP family, they formed the habit to their adolescent. One of the child in SP family in the last three months (September, October and November 2000) actively tried to foster himself by actively participating in activities at the mosque. Even sometimes he stays at the mosque and spent time with activity to perform five daily prayers. Interestingly, his participation and activity in the mosque were not due to encouragement from his parents but his own motivation. It was also his friends who invited him to be active in the mosque. On the other hand, other children in SP family were not active in the mosque because of their weak religious foundation and the weak system of moral formation in the family.

\section{Moral values Inculcation in the Families}

To answer this research question, this study found that moral values promoted in the families HD, DM and SP included morality towards Allah, towards others, towards the natural environment and self. Those values reflected their morality in every aspect that adolescent needs to perform.

According to parent in HD family, to help children to be pious with one of the indicators is that children are able to have good relationships with Allah. This is achieved by carrying out all His commands and stay away from everything He forbids. Implementing this to adolescent may establish a harmonious relationship between adolescent and Allah. They need to master certain material concerning the mastery of the procedures of worship and those which relate to mastery and understanding of prayers relating to worship to Allah. In this context, the father always taught about the importance of learning and mastering certain prayers related to religious rituals as well as those concerning the mastery of the recitation of the Quranic verses. In general, HD children were able to perform prayer services and reading the Quran. In conducting fasting Ramadhan, HD families including teenage children were able to carry out the obligation of fasting without failing to accomplish fasting. and doing it with patience and piety in a calm and peaceful atmosphere.

In order to boost faith and devotion to Allah, HD family was always present at the Commemoration of Islamic Holidays held by mosques as well as those held by neighborhood. HD adolescent is always actively involved in the Islamic Commemoration Day. In carrying out the zakat, HD's family implemented it, especially zakat fitrah and shadaqab which were submitted to the official committee to collect this. For a pilgrimage, HD had not been able to fulfill it, but according to his statement, he planned to conduct next year. This family had tried their best to perform Islamic worship that they could perform but in terms of financial capacity, they had a problem to accomplish it.

In DM family, fostering a relationship with Allah was done by performing ritual worship such as prayer, zakat and fasting with full obedience. DM parents always told their children to pray. Based on the questionnaire, one of DM's child stated that he sometimes left prayer. In DM family, adolescent carried out the five daily prayers in a timely manner and they could perform an obligation to conduct Ramadhan fasting. The adolescent in this family could perform all the worship that were obligatory for them to perform. In some occasion they missed the worship.

In terms of mastering the prayers and recitation of the Qur'an, DM's children always get used to reading the Qur'an after the Maghrib prayer. The above habits were carried out by 
parent and children. Regarding the implementation of the Maghrib prayer, the father occasionally carried it out in the mosque but it was mostly done at home. In order to boost the faith and devotion to Allah. DM family were always present at the commemoration of the Islamic Great Day held by the mosque. Although in some occasions, children were unable to attend. DM's family also seem to heed the principles that must be carried out by Muslim to Allah.

In SP family, this study found that they had not developed a proper relationship with Allah. This is due to the lack of a foundation of faith and devotion to Allah. This is to say that the adolescent had not carried out properly some worship activities like fasting. Unlike others, children number seven and number six could perform fasting well as do their parents.it can be said that some children in the family could perform worship and some did not perform worship to meet their obligatory worship to God.

In SP family, mastering the prayers and recitations of the Qur'an was done in an unconventional manner. Children number seven and six were able to read prayers and recite the Qur'an. Other children lacked mastery in prayers and Qur'an reading skill. Other worship activity like fulfilling the zakat, SP family could pay it but not in a regular manner since they are economically classified as a pre-prosperous family. Even every year this family received a portion of zakat from the rakat committee. Given this circumstance, in SP family there were many discrepancies that they needed to fulfill to Allah.

The relationship between fellow humans emphasizes the relationship between children and parents. In HD family, adolescent behaved well to their parent. They seem very obedient and respectful to their parents. They were also able to maintain harmonious communication in daily life with their sister and brother. Likewise, in HD family parent were very fond of their children and created an atmosphere of openness, compassion, and harmony. Both parent and children in this family were able to build good and supporting a positive relationship that may support adolescent moral development.

In DM family, this study found several things. Based on observations, it was found that the communication between the parents and their adolescent seemed poor. There was a kind of rigidity and attitude on the part of the father towards his children. Likewise, there was a lack of good emotional relationships between parents and children. The parents exhibited more authoritarian attitudes in developing moral formation for their children. On the contrary, adolescents 'attitudes toward their parents seem to be very obedient and respectful. Although sometimes they denied their parents' policies. This happened because of lack of openness and closeness between father and adolescent.

In SP family, this study found several things. The adolescent in some occasion opposed to their parents' orders. On one occasion, three children helped their mother's work at home. In the DM family, communication between parents and children was not well established. For instance, they rarely had a joke and discuss something in their nature. In addition, the relationship among children in SP family lacked a sense of brotherhood and family ties. This could be seen from their attitude and daily behavior that was not conducive and uncomfortable since there were many disputes among children.

Regarding the moral guidance between wife and husband, in HD family, it was very well developed. HD's wife was very respectful and obedient to her husband. Likewise, the husband was very respectful and caring for his wife in an atmosphere of harmony. They developed mutual trust, openness, compassion, and their respective responsibilities in accordance with the rights and obligations of husband and wife. Both father and mother in this family exhibited good and sound example behavior for their children to imitate by their adolescent.

In DM's family, moral development between husband and wife in some matters concerning their rights and obligations was good. Concerning certain attitudes, on some 
occasion the wife exhibited less respectful. Sometimes she imposed her opinion as something that is considered true. The husband tried to manage the situation because he understood his wife's character. This condition did not contribute to family and adolescent moral development in the family. They could not perform harmonious and well-managed relationship to be imitated by their children for their moral development.

Related to moral formation towards their neighbors, in HD family parent and their teenagers exhibited good performance. HD children were perceived as good by their neighbors. They exhibited good behavior and they were able to mingle with their neighbors/ surrounding communities. They often talked and always did voluntary work together with their neighbors, so that they were familiar and easily recognized. The father in HD family always visited dead person took care of the dead body. He used to help neighbors at times of trouble, visit neighbors at the time of illness. Moreover, he never disturbed the tranquility of neighbors, fought with neighbors, and other misconduct behavior.

In DM family, this study found that they seemed to be inadequate in developing relationships with their neighbors. The parent sometimes was active in the study of the majlis ta'lim as a means of communicating with neighbors, but they were involved in a dispute with their neighbors. The children were not so close to his fellow teenagers around them. One of the child was more likely to hang out with friends at school and other child was busy at school and doing sports (second child). Their behavior is not in accordance with the theory used in this study.

In SP family, the mother and most of her children seemed less close to their neighbors. The teenager could maintain well the relationship with his fellow friends and neighbors. In contrast, the father was less able to develop relationships with his neighbors. He rarely conducted communication with neighbors and preferred to stay at home. In addition, the father never responded to the environmental service program in the society, never attended the recitation, as well as the disaster that struck his neighbors. These behaviors do not seem to be in accordance with the theory in this study concerning social creature relationship with another human.

In fostering the moral values of adolescents towards the natural environment, HD father was very good at maintaining relations with the natural environment. This study found that he and his children usually cleaned yard and took care of and watered the flowers every day. In addition, HD children cleaned the floor of the house, washed and swept inside and outside the house. They could perform these good behaviors because their parent always showed the examples and set habituation shown by their parents. So there was a sense of awareness in their children to do this behavior regularly.

Similarly, in DM family, they exhibited good moral character to the natural environment: the parent was very diligent in cleaning their environment, caring for and watering flowers and trees in front of their house every day. Likewise, their teenager diligently cleaned their house such as sweeping, mopping the floor and washing dishes. This circumstance was positive and contributed to adolescent moral development because both parent and children could perform to manage cleanliness for their home.

In SP family, the children were less diligent in carrying out environmental hygiene (such as a sweeping and cleaning small river). They must always be ordered by their parents to work on the cleanliness of the house and its environment. Meanwhile, their parent was very active in cleaning their own yard. For voluntary work, the father never participated and he asked his children to represent him for voluntary service.

In HD family, the children could succeed to perform moral to oneself through the advice and example given by their parents. The behaviors that the adolescent exhibits are: being loyal to both parents, keeping promises, being fair, maintaining self-purity, feeling 
embarrassed to make mistakes, being patient in facing trials, loving affection, helping others, behaving peacefully with others, respecting guests, being humble, doing good to others, feeling grateful on their condition.

In DM family, their adolescents could perform several good behaviors including Keeping promises, doing the right, maintaining self-purity, feeling shame to do bad action, respecting guests and worshipping God. Those behaviors were good and they reflected good behavior that adolescent perform in their daily life. These children were able to perform good behavior that can build a good relationship with their society.

In SP family, the parent taught their teenagers good behaviors including patience, mutual cooperation, and qanäah. The study found that their adolescent had only performed a small portion of morality.

\section{Parents' Approaches and Methods to Develop Adolescent Moral Values}

Regarding this issue, there are several findings from the families involved in this study found. In HD family, the parent used a rational/normative approach and method to teach moral. The father gave reasons and rational explanations and rules of religion and rules in the community (normatively) in giving advice and in dealing with problems faced by adolescents. Likewise, the emotional approach is very inherent in moral formation towards their children. The experience / empirical approach was used by the father for instance in providing practical examples in the form of direct involvement in doing certain work. The sociological approach emphasizes adolescent morals development by giving advice and examples in an effort to involve themselves in people's lives, mingle, communicate and interact with the surrounding community. In HD family, the parent and children were always at the forefront of pioneering these social activities. Culturally, the father always instilled in his adolescent the importance of dynamism and enthusiasm for working at home and at school.

HD family applied the method of modeling and habituation in fostering moral values towards their adolescents. It included the principles of reward and punishment. Exemplary action and habituation were one of the methods applied by the father. He provided his children many examples and habits so that his children could follow and imitate all aspects of the behavior. These behaviors can be in the form of words, deeds, emotions, mindsets, and ways to solve problems for teenagers.

In DM's family, rational normative approaches and methods of habituation were used as the basis for fostering moral values of adolescents. It can be in form of, gift principles (targhib) and rigid punishment (tarbib). Based on the observation, the father always gave reasons/ explanations rationally/ normatively in giving advice and guidance to his children. For example, the parents were very strict to their children if they violated the norms. The experience/ empirical approach was used by the parent when they provided a practical example in the form of direct involvement from the parent in conducting and giving examples of specific jobs. The sociological approach was applied to develop moral values. The parent guided their children by giving advice and examples in an effort to involve themselves in people's lives, mingle, communicate and interact with the surrounding community. This study found that the effort instilled by parent did not work. Their children were busy pursuing extracurricular work at school so that they could not participate in society.

DM family applied the method of modeling and habituation, including the principles of reward and punishment in fostering moral values towards their adolescents. Exemplary action and habituation were one of the methods applied by the mother. She provided her children with many examples and certain habits so that her children could follow and imitate all aspects of the behavior. The implementation of this method was suitable for teenagers to associate their actions and instill transcendental aspects (bablun minalläh). 
In SP family, the punishment approach in developing moral values for their teenagers was preferable. The study found that the parents developed more abusive attitudes towards their children. On the other hand, the example model approach was not developed in the family. The development of experiential approaches, especially those concerning the responsibilities and awareness of daily tasks at home in general, their adolescent were very good. They lacked the example model and habituation to the aspects of worship and the ethics of speaking. The method developed by the SP family in fostering moral values towards their adolescents was to develop a punishment method (tarbib), where parents gave more orders and provided less emotional relationships.

\section{Circumstance for Adolescent Moral Values Development}

This section explores the findings on circumstances of moral value development in families involved in this study. The study found that in HD family, there were supporting circumstances for instilling moral values. In the guest room, there was a family photo and calligraphy that showed an atmosphere of calm, shade and religious nuances. Besides that, there were a number of reading books, both concerning religion and general, which were arranged neatly. This is an indication that HD family had a great interest in understanding religious issues.

Concerning non-physical aspect, HD family featured a harmonious relationship among members of the HD family. The supporting situation for moral values development existed like mutual respect, courtesy, intimacy, each carrying out their duties and roles fairly. The Mother with her gentle words devoted her love to her children. Greeting, shaking and kissing the hand of a parent were regular scenes when the children wanted to leave the house.

In terms of physical aspect for HD family, the house where they lived could send messages to support adolescent moral values. The house was well-decorated with several accessories rooted from religious messages. The religious accessories available in the house may bring a good atmosphere for adolescent moral development.

Psychological conditions also appear to develop in HD's family. The father was wise and the mother was full of the atmosphere of warmth in mingling with their teenager. Their words were good and carried with good intonation. This condition has been able to encourage the adolescent in a family to learn moral in a conducive way. The climate of the family atmosphere developed in HD family supported the creation of a process of identification, internalization, transformation and the value of moral character developed in this family. Without those supporting psychological aspects, adolescent moral development would be difficult.

Like HD family, SP and DM family had several supporting physical circumstance to support moral education in their home. Things like calligraphy and well-designed interior were available. in SP house, it had several rooms to cater to family needs. It featured a living room, bedroom, kitchen, and other space. The house is well-organized and looked clean because of good maintenance in terms of its hygiene.

In terms of the non-physical aspect, DM family had shown less atmosphere of intimacy because there was a lack of openness between them. Psychologically, DM family had not built optimally their family relationship. This supporting atmosphere for a family relationship was crucial for adolescent moral development. To achieve good psychological aspect to support adolescent moral development, parent needed to pay attention to this aspect.

\section{Theoretical Analysis}

The pattern of moral development can be implemented by parents towards adolescents in a process of interaction and internalization in family life. The process is hoped that the achievement of moral character reflected in daily life is based on Islamic values. Al-Ghazali, 
(1994) in his masterpiece, Ibyā 'Ulümiddin, explains that good morals can be achieved through persistent efforts with good methods. Moral Improvement can be achieved through appropriate moral effort and practice. To achieve good morals or temperament, there are two methods to do; First, through the method of experience (al-tajribab) and second is methods of practice (riyädhah).

Akblaq karimah can be taught to adolescent if the basic elements for upholding morals can run synergistically in the process of family life. Parents' clear vision and mission, good atmosphere, playmates and the experience and self-training are basic elements in the formation of akblaq karimah for adolescents. Good character will not be achieved if the basic elements are not met. Thus the presence of parents in adolescent moral development in the family plays a very important role.

Parent role is crucial in nurturing akblaq karimah Especially their role as a guide and as an example of the main example in the plan of the noble moral character. Al-Ghazali views that giving a good experience in moral formation is very important. The opportunity to pay attention to people who are good at temperament and associate with them. There is a saying "Experience is a very good teacher". So if you want to generate children who have good character, facilitate them a habit to live with good people. Because indirectly in their association there is a process of imitating the character of someone who is not aware of it (Quasem, 1988).

Good morals can also be obtained by getting along with good people and associating with them. Naturally, human being imitates behavior. This is to say that in human relationship, a person unconsciously gets good and bad from other people's character. It shows that there is an influence on human relationship toward other humans when interacting.

In the moral formation of children, a spiritual guide is needed. They need a real and living example for a moral formation to exist. In the presence of the supervisor, the adolescent can be on the right path in terms of their behavior. The supervisors are responsible for guiding, directing and paying attention to the morals of the adolescent when they misconduct. They act as a counselor and perform wisely to correct it. Conversely, if children do an act that is commendable or a noble deed, then the supervisor can reinforce and encourage them and ask them to maintain and improve the deed.

A reward can be given to adolescent which serves as an expression of support for their positive behavior. Thus the presence of the spiritual guide for adolescents is very important for the formation of their good moral character. As explained by al-Ghazali who was quoted by Quasem (1988), he explained that "The first step in improving bad morality is by providing a student with a spiritual guide. The guiding person watches carefully and declares student's shortcomings".

In their life, adolescents need friends. The presence of a friend cannot be separated from their life. They can be a partner in learning, playing and so on. Much of the lives of teenagers are spent by communicating with their peer groups. Therefore the presence of friends in adolescent relationships is very important to be noticed by parents. Otherwise, a bad friend can influence adolescent to act immorally like drinking alcohol and brawl.

Similarly, an adolescent can be a pious child because of friendship influence. Because adolescent friendship is influential, parents need to pay attention to their adolescent friends. Several questions that parents need to consider when it comes to their adolescent friendship. What kind of adolescent is their friend? How and where do their adolescent play? These questions pose a significant benefit to monitoring their adolescent communication. In the process of their adolescent communication, there will be a mutual influence among them. There are several possibilities: positive or negative, correction, and the process of mutual counseling. The importance of the presence of a friend for moral formation as explained by 
al-Ghazali who was quoted by Quasem (1988) as follows: some Steps to improve their adolescent morality by asking for help from a friend who has noble character and is able to observe and stated their shortcomings.

In his masterpiece, al-Ghazali emphasized the importance of parents' role in providing exercises and habituation to doing good deeds for their children. In the process of moral formation given by parents, it seems that it will be more effective than material explanations given by lectures for the adolescents. Especially at the age of elementary school adolescent exemplify the behavior of their mother and father or those who are close to them. The importance of this habituation aspect as explained by al-Ghazali, which is quoted by Quasem (1988) as follows: "If parents are to familiarize their children and teach them well, surely their children will grow on the basis of that goodness and immorality in the world they live".

In other parts, al-Ghozali emphasizes the importance of parents to train and teach the Qur'an and hadith to children in order to achieve good morals. Al-Qur'an and hadith are the main sources of Islamic teachings that need to be given to children from an early age. By practicing reading the Qur'an and the hadith, the love of the holy book of the Koran and love the Prophet will start to grow. Furthermore, al-Ghazali suggests that children need to be taught the stories of pious people. By teaching this story, it is expected that the children can remember and imitate the deeds of the pious people. This is a contribution towards the formation of adolescent good moral character. As explained by al-Ghazali who was quoted by Quasem (1988) as follows: "In school children must be taught the Qur'an hadith and stories of pious people, so that their love for these things is embedded in their memory ".

In addition to teaching the Qur'an and the hadith for adolescent, the aspect of nurturing moral lesson is an important part in the formation of their morals. They will feel very close and familiar psychologically with the people who care for them. They will be easily influenced by the character and actions of the caregiver. In line with this, al-Ghazali emphasizes that children should be taken care of by pious women, including breastfeeding activity.

The last part of al-Ghazali's theory concerns emphasis on the importance of parents to train children to be humble and to respect their friends and groups. Without proper education on noble character, adolescent tends to be arrogance. They may feel proud of their wealth, good looks and their descendants. This behavior and attitudes are not justified. To get rid of these arrogant qualities, al-Ghazali stressed the need for an adolescent need to be trained humbly, to respect others and perform good manners in behavior. As explained by al-Ghazali who was quoted by Quasem (1988) as follows: "respect for friends and groups and hospitality should be taught to children. They should be banned from boasting of their parents' property, food, clotbing and so on. The richest children must be educated about the virtues of giving alms, while the poorest children must be taught that greed and taking other people's things are despicable and shameful."

Thus to form a moral character is very important for parents to train and familiarize children early in behaving well, at home or outside the home through guidance, direction, supervision, and examples. It is expected that they will be accustomed to good character in their life.

\section{CONCLUSION}

This study investigated adolescent moral education development in families. In a summary, the goals and objectives to be achieved by HD, DM and SP family in developing moral of their adolescents were to have pious children. The children were expected to be obedient to God Almighty, respectful to parents and be able to behave well towards fellow human beings. Given the similar objective, each family applied various method and approach to instill moral values to their adolescent. 
HD and DM families managed well their moral education for their adolescent in worshipping Allah. They succeeded because they were able to provide examples, habituation, advice and physical and psychological atmosphere to nurture their adolescent moral towards Allah. Their achievement is in accordance with al-Ghazali's theory of the importance of improving morals through habituation, example, and experience. SP family in contrast, could not achieve well because parents were less able to provide examples and religious atmosphere in the family.

In terms of moral development for fellow human beings toward their adolescent, HD had achieved it since the parent succeeded in providing examples, advice, experiences and habits in developing relationships with others. Whereas in DM and SP families, they had not achieved well because the parents were less able to provide examples, guidance and habituation in developing relationships with others.

\section{BIBLIOGRAPHY}

Abu, L., Mockhtar, M., Hassan, Z., \& Suhan, S. Z. D. (2015). How to develop character education of madrassa students in Indonesia. Journal of Education and Learning, 9(1), 79_ 86. https://doi.org/ 10.11591/edulearn.v9i1.768

Al-Ghazali. (1994). Ibya 'Ulumiddin. (H. M. Zuhri, Trans.). Semarang: CV Asyifa.

Ardi, Z., Viola, K., \& Sukmawati, I. (2018). An analysis of internet abuses impact on children's moral development. JPPI Jurnal Penelitian Pendidikan Indonesia), 4(1), 44-50. https://doi.org/ 10.29210/02018192

Bawazir, D., Murwani, R. S., Suryotomo, S. H., Nasution, Y., \& Buriswati, E. (2009). Peran pendidikan keluarga dalam pembinaan moral remaja menghadapi era globalisasi. Jurnal Ilmu Pendidikan Universitas Negeri Malang, 1(2). http://dx.doi.org/10.17977/jip.v1i2.2270

Hidajah, S. H. (2012). Problema pengembangan moral remaja dalam perspektif pendidikan Islam. Dinamika Ilmu, 12(1). http://dx.doi.org/10.21093/di.v12i1.55.

Hidayat, N. (2016). The implementation of character education model at Islamic Boarding School of Pabelan, Magelang, Central Java. Jurnal Pendidikan Islam, 5(2), 431-455. https:// doi.org/ 10.14421/jpi.2016.52.431-455

Kanzal, V. R. (2016). Moral education: Current values in students and teachers' effectiveness in inculcating moral values in students. Moral Education, 14. Retrieved from https:/ $/$ www.ijip.in/index.php/?view $=$ article\&id $=974$.

Mosher, R. L., \& Sullivan, P. R. (1976). A curriculum in moral education for adolescents. Journal of Moral Education, 5(2), 159-172. https://doi.org/. https://doi.org/10.1080/0305724760050205

Muntaha, P. Z., \& Wekke, I. S. (2017). Paradigma pendidikan Islam multikultural: Keberagamaan Indonesia dalam Keberagaman. Intizar, 23(1), 17-40. https://doi.org/10.19109/intizar.v23i1.1279

Nadhif, A. (2016). Religious values in Indonesia's character education. Jurnal Pendidikan Islam, 27(1), 128-141. https://doi.org/10.15575/jpi.v27i1.500

Niwaz, A., Ishfaq, U., \& Attaulah. (2018). Morality in the light of Quran and Hadits: A Critical analysis of parent and teachers' role as family and public institution. Journal of Islamic and Religious Studies 3, (1), 49-59. Retrieved from http://www.uoh.edu.pk /jirs/previous-issues-papers.php?id $=94$

Quasem, M. A. (1988). Etika Al-Ghara. Bandung: Penerbit Pustaka.

Ramayulis. (1996). Pendidikan Islam dalam rumah tangga. Jakarta: Kalam Mulia.

Rifai, M. S. S. (1984). Psikologi perkembangan remaja dari segi kehidupan sosial. Jakarta: Bina Aksara. 
Shihab, M. Q. (1992). Membumikan al-Quran. Bandung: Mizan.

Syam, M. N. (1988). Pengantar dasar-dasar pendidikan. Malang: Usaha Nasional.

Tafsir, A. (1992). Ilmu pendidikan dalam perspektif Islam. Remaja Rosdakarya. 